\title{
Mutants of Salmonella typhimurium \\ Responding to Cysteine or Methionine: Their Nature and Possible Role in the Regulation of Cysteine Biosynthesis
}

\author{
By M. A. QURESHI,* D. A. SMITH AND A. J. KINGSMAN \\ Genetics Department, Birmingham University, Birmingham BI $52 T T$
}

(Received 23 December 1974; revised 12 March 1975)

\begin{abstract}
SUMMARY
Nineteen mutants of Salmonella typhimurium responding to either cysteine or methionine (cym) have been identified amongst cysteine (cys) and methionine (met) auxotrophs. Their growth responses to known intermediates in the related pathways of cysteine and methionine biosynthesis and complementation patterns in abortive transduction tests divided the mutants into six groups. Results of conjugation, cotransduction and deletion mapping experiments substantiated these groups, each of which carried a lesion within known cys genes. Enzyme assays on cym mutants from five of the six groups confirmed their cys gene deficiencies. Growth response and enzyme assay data were not consistent with cym mutants being leaky cys mutants (spared by methionine). None of eight cym mutants tested were able to convert $\left[{ }^{35} S\right]$ methionine into $\left[{ }^{35} \mathrm{~S}\right]$ cysteine. Selenate specifically inhibits the early enzymes of cysteine synthesis. In cym mutants this inhibition was relieved by cysteine but not by methionine, indicating that cym mutants require active cys enzymes for growth on methionine. There was evidence that methionine stimulated in vivo activity of cys enzymes in a cym mutant. Resistance to inhibition by $1,2,4$-triazole results in reduced levels of the $O$-acetyl serine sulphydrylase. In cym mutants triazole resistance gave unstable suppression of the cym phenotype. Cym mutants may result from mutation in regulatory regions common to each of the cys genes, with the precise role of methionine as yet unknown.
\end{abstract}

\section{INTRODUCTION}

The biochemical and genetical aspects of the nature and regulation of cysteine and methionine synthesis in Escherichia coli and Salmonella typhimurium have been reviewed (Smith, 197I), and additions in relation to methionine synthesis in E. coli were recently made by Ahmed (1973). The two metabolic pathways are interrelated (Fig. I) and both involve structural genes which, although showing some clustering, are mainly scattered around the genetic maps (Fig. 2). End-product repression control operates in both pathways. Induction of cysteine enzymes by $O$-acetyl serine (Fig. I) is well established (Kredich, 197I) and an interesting parallel role of methionine precursors in relation to methionine synthesis has been proposed (Whitehouse \& Smith, I973). Synthesis of cysteine is under positive control whereas that of methionine is negative. Although regulatory mutants for both systems exist, the nature of the regulatory proteins and their effectors are still incompletely understood. There is now a strong implication that $\mathrm{S}$-adenosylmethionine is the methionine corepressor (Hobson, 1974) and that both vitamin $B_{12}$ (Whitehouse \& Smith, 1973) and at least one of the enzymes involved in homocysteine methylation (Whitehouse \& Smith, 1974) are concerned in methionine regulation.

\footnotetext{
* Present address : 48 Shah Din Scheme, Ichhra More, Lahore, Pakistan.
} 


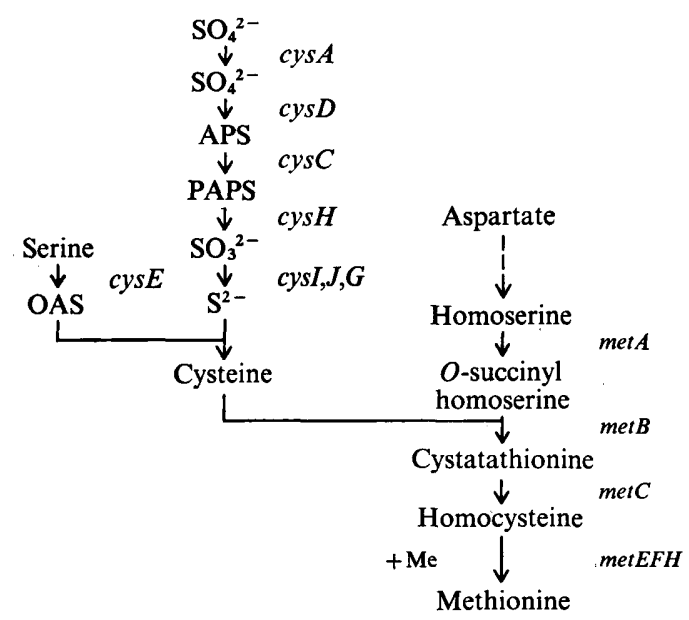

Fig. I

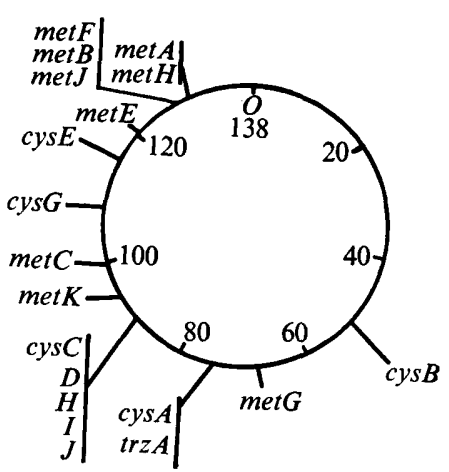

Fig. 2

Fig. I. S-amino acid synthesis in Salmonella typhimurium. cys $A$, sulphate permease; cys $C$ and cys D, ATP-adenylsulphate $5^{\prime}$-phosphotransferase and ATP sulphate adenylyl transferase (ATP sulphurylase), respectively (these enzymes together constitute PAPS synthetase); $c y s E$, serine transacetylase; cys $H$, adenosine $3^{\prime}$-phosphate $5^{\prime}$-sulphatophosphate reductase (PAPS reductase); cys $G, I, J$, hydrogen sulphide: NADP oxidoreductase (sulphite reductase); met $A$, homoserine- $O$ transsuccinylase; met $B$, cystathionine- $\gamma$-synthetase; met $C, \beta$-cystathionase; met $E$, $N^{5}$-methyltetrahydropteroyltriglutamate-homocysteine transmethylase (cobalamin-independent methylase); $\operatorname{met} F, N^{5} N^{10}$-methyltetrahydrofolate reductase (tetrahydrofolate reductase). OAS, $O$-acetyl-Lserine; Me, methionine.

Fig. 2. Abbreviated linkage map of Salmonella typhimurium (after Sanderson, 1972). Mutant symbols as in Fig. I; trz, triazole resistance. Numbers indicate time intervals in min.

During the course of extensive work with many different auxotrophs of $S$. typhimurium initiated in the late Dr M. Demerec's laboratory at Cold Spring Harbor in the mid-1950s, mutants responding equally well to either cysteine or methionine were isolated but not investigated. Qureshi (1968, 197I) recognized similar mutants amongst newly isolated methionine auxotrophs of the same organism, and initiated further studies of them in an attempt to shed light on the general regulation of S-amino acid metabolism. This paper reports physiological, genetical and enzymological experiments with nineteen cysteine/ methionine (cym) auxotrophs which implicate methionine in the regulation of the synthesis of all known cysteine enzymes. Mutations conferring resistance to inhibition by $1,2,4^{-}$ triazole, which probably interferes with induction of the cysteine enzymes (Hulanicka, Klopotowski \& Smith, 1972; Jones-Mortimer, 1968; Hulanicka \& Klopotowski, 1972) suppress cym mutants. The stability of this suppression is variable and its nature not only relates to cysteine gene regulation but also to plasmid involvement in suppression (Kingsman, unpublished) probably extending beyond the cysteine system (I. M. Packer, personal communication).

\section{METHODS}

Organisms and materials. Salmonella typhimurium LT2 was the wild-type bacterium from which all the mutants used (Table I) were derived. The phenotypic designation cym for the cysteine or methionine mutants may not be permanent: it is retained in this paper for clarity. Nutrient broth and agar media (NB and NA), and minimal liquid and agar media, (MM and MA) were those of Smith (196I), except that in sulphur-free minimal medium [MM(sf)] 
Table I. Mutants of Salmonella typhimurium LT2

\begin{tabular}{|c|c|c|c|c|c|c|}
\hline Mutant & $\begin{array}{c}\text { Cym } \\
\text { designation }\end{array}$ & $\begin{array}{c}\text { Previous } \\
\text { designation }\end{array}$ & $\begin{array}{c}\text { Other } \\
\text { markers }\end{array}$ & $\begin{array}{c}\text { Mode of } \\
\text { origin }\end{array}$ & $\begin{array}{l}\text { Other } \\
\text { properties }\end{array}$ & Source* \\
\hline cymI & $\mathrm{Aa}$ & 23 & . & NTG & 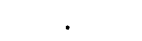 & M.A.Q. \\
\hline cym2 & $\mathrm{Ab}$ & 28 & . & NTG & ts & M.A.Q. \\
\hline cym3 & $\mathbf{B a}$ & 55 & . & NTG & ts & M.A.Q. \\
\hline cym4 & $\mathbf{B a}$ & 72 & . & NTG & ts & M.A.Q. \\
\hline cym5 & $\mathrm{Bb}$ & cys-7I & . & $\mathrm{sp}$ & . & K.E.S. \\
\hline cym6 & $\mathrm{Bc}$ & cys -72 & . & sp & ts & K.E.S. \\
\hline cym7 & Aa & cys -177 & ara-9 & sp & ts & K.E.S. \\
\hline cym8 & $\mathrm{Bb}$ & cys -204 & ara-9 & $2 \mathrm{AP}$ & ts & K.E.S. \\
\hline cym9 & $\mathrm{Cb}$ & cys -205 & $a r a-9$ & $2 \mathrm{AP}$ & . & K.E.S. \\
\hline cymio & $\mathrm{Cb}$ & cys -286 & . & $2 \mathrm{AP}$ & . & K.E.S. \\
\hline cymI I & $\mathrm{Cb}$ & cys -288 & . & $2 \mathrm{AP}$ & . & K.E.S. \\
\hline cymi 2 & $\mathrm{Ca}$ & cys -333 & . & u.v. & . & K.E.S. \\
\hline cymi3 & $\mathrm{Ab}$ & cys-797 & . & $2 \mathrm{AP}$ & . & K.E.S. \\
\hline cymI 4 & $\mathrm{Ca}$ & cys-798 & . & $2 \mathrm{AP}$ & . & K.E.S. \\
\hline cymi 5 & $\mathrm{Bc}$ & cys -803 & . & $2 \mathrm{AP}$ & ts & K.E.S. \\
\hline cymi 6 & $\mathrm{Bb}$ & cys -896 & . & 2AP & . & KES \\
\hline cymi 7 & $\mathrm{D}$ & cys -898 & 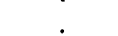 & $2 \mathrm{AP}$ & . & K.E.S. \\
\hline cymi 8 & $\mathrm{Bb}$ & cys-1053 & . & $5 \mathrm{BU}$ & . & K.S.S. \\
\hline mig & $\mathrm{Ab}$ & cys-1219 & 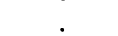 & NTG & ts & K.E.S \\
\hline
\end{tabular}

B. Other mutants

\begin{tabular}{|c|c|c|c|c|c|c|c|}
\hline Mutant & $\begin{array}{l}\text { Other } \\
\text { markers }\end{array}$ & $\begin{array}{l}\text { Other } \\
\text { proper- } \\
\text { ties }\end{array}$ & Source & Mutant & $\begin{array}{c}\text { Other } \\
\text { markers }\end{array}$ & $\begin{array}{l}\text { Other } \\
\text { proper- } \\
\text { ties }\end{array}$ & Source* \\
\hline cys $A 20$ & . & $\mathrm{dl}$ & K.E.S. & cysD505 & . & . & K.E.S. \\
\hline cysA2I & . & . & K.E.S. & cysG439 & . & . & K.E.S. \\
\hline cys $A 22$ & . & . & K.E.S. & cys $\mathrm{H}_{47}$ & gal-24 trp-7 & & K.E.S. \\
\hline cysA69 & . & . & K.E.S. & cysH75 & . & dl & K.E.S. \\
\hline cysAI97 & $a r a-9$ & . & K.E.S. & cys $H_{3} 64$ & . & dl & K.E.S. \\
\hline cysA2OI & ara-9 & . & K.E.S. & cys $H_{398}$ & . & dl & K.E.S. \\
\hline $\operatorname{cys} A_{35 I}$ & . & & K.E.S. & cys $\mathrm{H}_{572}$ & . & $\mathrm{dl}$ & K.E.S. \\
\hline cys $A 533$ & . & $\mathrm{dl}$ & K.E.S. & cysI5I & . & & K.E.S. \\
\hline cys $C 218$ & ara-9 & & K.E.S. & cys 168 & . & $\mathrm{dl}$ & K.E.S. \\
\hline cysC 520 & . & dl & K.E.S. & cysI295 & $a r a-9$ & & K.E.S. \\
\hline cys $C_{532}$ & . & & K.E.S. & cysHI36 & . & dl & K.E.S. \\
\hline cys $C 537$ & . & $\mathrm{dl}$ & K.E.S. & cysHI536 & . & $\mathrm{dl}$ & K.E.S. \\
\hline cysCD519 & . & $\mathrm{dl}$ & K.E.S. & cysJ 299 & $a r a-9$ & . & K.E.S. \\
\hline cys $C 700$ & . & & K.E.S. & cysJ 447 & . & & K.E.S. \\
\hline cysC 710 & . & dl & K.E.S. & cysJ $J_{538}$ & . & $\mathrm{dl}$ & K.E.S. \\
\hline cysCIOZI & . & dl & K.E.S. & metAIs & . & $\mathrm{dl}$ & D.A.S. \\
\hline cysD220 & . & dl & K.E.S. & metF96 & . & . & D.A.S. \\
\hline \multirow[t]{2}{*}{$\operatorname{cys} D_{305}$} & . & - & K.E.S. & $\operatorname{trzI} 2$ & . & . & A.J.K. \\
\hline & & & & trzi Io & . & . & A.J.K. \\
\hline
\end{tabular}

2AP, 2-aminopurine; $5 \mathrm{BU}, 5$-bromouracil; NTG, $N$-nitroso- $N^{\prime}$-nitro- $N$-nitrosoguanidine; sp, spontaneous ; u.v., ultraviolet light; dl, deletion; ts, temperature-sensitive; cys, met, and trp, genes involved in cysteine, methionine and tryptophan biosynthesis; ara and gal, genes involved in utilization of arabinose and galactose; trz, triazole resistance.

* A.J.K. (Mr A. J. Kingsman), M.A.Q. (Dr M. A. Qureshi) and D.A.S. (Dr D. A. Smith) of Birmingham University, and K.E.S. (Dr K. E. Sanderson) of the Department of Biology, The University, Calgary, Alberta, Canada. 
$0.8 \mathrm{I} \mathrm{g} \mathrm{NH} \mathrm{Nl}_{4} \mathrm{Cl}$ and $0.04 \mathrm{~g} \mathrm{MgCl} .6 \mathrm{H}_{2} \mathrm{O}$ were added to each litre instead of $\mathrm{K}_{2} \mathrm{SO}_{4}$ and $\mathrm{MgSO}_{4} \cdot 7 \mathrm{H}_{2} \mathrm{O}$. Media supplementation, culture and subculture procedures, dilutions, assays, and routine testing and storage of all bacterial strains were also those of the same author. Concentrations of cysteine and methionine precursors and related compounds used were: sulphite and sulphide, ro $\mu \mathrm{g}$ sulphur/ml; thiosulphate, Io $\mu \mathrm{g}$ and I mg sulphur/ $\mathrm{ml}$ (Clowes, 1958); cysteine, L-allo-cystathionine, L-homocysteine thiolactone $\mathrm{HCl}$ and L-methionine, $20 \mu \mathrm{g} / \mathrm{ml}$; vitamin $\mathrm{B}_{12}, \mathrm{I} \mu \mathrm{g} / \mathrm{ml}$; djenkolic acid, $38 \cdot \mathrm{I} \mu \mathrm{g} / \mathrm{ml}$.

$\left[{ }^{35} \mathrm{~S}\right]$ sulphate (carrier-free) and $\left.{ }^{35} \mathrm{~S}\right]$ methionine were obtained from the Radiochemical Centre, Amersham, Buckinghamshire. Phage $\mathrm{P}_{22}$ and, less frequently, its non-lysogenizing derivative L4 (Smith \& Levine, 1967) were used for transduction. The preparation and storage of phage lysates were as described by Smith (196I) except that lysates were occasionally prepared from confluently lysed lawns of bacteria instead of liquid cultures. All incubations were at $37^{\circ} \mathrm{C}$ unless otherwise stated.

Mutagenesis. Overnight NB cultures of wild-type bacteria were washed and resuspended in the same volume of $\mathrm{MM}$, diluted $\mathrm{I}: 20$ in $\mathrm{MM}+N$-methyl- $N^{\prime}$-nitro- $N$-nitrosoguanidine (NTG) and then incubated for 30 min (after Eisenstark, Eisenstark \& van Sickle, 1965). These suspensions $\left(0.3\right.$ to $0.5 \%$ survival) were diluted $\mathrm{IO}^{-3}$ and $1 \mathrm{O}^{-4}$ in saline $(0.85 \% \mathrm{w} / \mathrm{v}$, $\mathrm{NaCl})$ and appropriate volumes plated on to $\mathrm{MA}+0.02 \%(\mathrm{w} / \mathrm{w}) \mathrm{NB}$ and NA. After $48 \mathrm{~h}$ incubation small colonies were picked from both enriched MA and NA plates and subcultured on to NA. These subcultures and the remaining large colonies from the original NA plates were replicated to MA and MA + methionine. Apparent methionine auxotrophs were subcultured to give single colonies whose phenotype was rechecked by similar replication before the establishment of triplicate stock subcultures from a single colony. Forty-six stable methionine auxotrophs were derived from enriched MA, and 24 from NA.

Growth responses. Initially, growth responses and the heat sensitivity of mutants were determined on solid media. Overnight NB cultures were washed in saline and loopfuls streaked on to each of three MA or appropriately supplemented MA plates. Single plates were then incubated at 25,37 and $42{ }^{\circ} \mathrm{C}$ and growth responses observed during at least $48 \mathrm{~h}$. If growth of a mutant at $25^{\circ} \mathrm{C}$ was similar to that of wild type at the same temperature and clearly less than that of wild type at 37 or $42{ }^{\circ} \mathrm{C}$, it was designated heat sensitive (Smith \& Childs, 1966 ).

More precise measurements were made in liquid culture. Overnight cultures in $\mathrm{MM}+$ methionine or djenkolic acid were diluted $\mathrm{I}: 5(\mathrm{v} / \mathrm{v})$ into fresh medium and incubated for 90 min. Bacteria were then washed twice, resuspended in either MM or MM(sf), and appropriate volumes added to $50 \mathrm{ml}$ prewarmed test media in $250 \mathrm{ml}$ conical flasks to give an $E_{650}$ of 0.05 to 0.06 measured in a Unicam SP500 spectrophotometer, using a glass cuvette of $\mathrm{I} \mathrm{cm}$ light pathway. During continued incubation, samples were removed every 30 to $60 \mathrm{~min}$ and their turbidity recorded. Extinction was plotted on a log-linear scale against time of sampling. Mean generation times were deduced from the graphs as the time required for a twofold increase in $E$.

Transduction. The whole-plate technique to select recombinants for replication analysis was that of Smith (196I). To detect complete and abortive transductants when large numbers of pairs of auxotrophs were crossed, the spot method of Hartman, Hartman \& Šerman (1960) as modified by Smith \& Childs (1966) was used. In the cotransduction experiments all selective plates (except those for crosses in which the donor was cymCbI I) were incubated for $48 \mathrm{~h}$ and replicated to selective plates which were incubated for 10 or for 16 to $20 \mathrm{~h}$, depending upon the cys recipient. With cymCbI I strains, recombinants of the donor phenotype could be detected as small colonies after $72 \mathrm{~h}$ incubation of the selective plates; replica plating was unnecessary. 
Table 2. Mean generation times of cym and other mutants in sulphur-free minimal medium at $37^{\circ} \mathrm{C}$ with and without cysteine or methionine

$\begin{array}{lccc}\text { Mutant } & \text { MM(sf) } & \begin{array}{c}\text { MM(sf)+ } \\ \text { cysteine }\end{array} & \begin{array}{c}\text { MM(sf)+ } \\ \text { methionine }\end{array} \\ \text { cysCD } 5 \text { I9 } & \alpha & 82 \cdot 5 & \alpha \\ \text { metF96 } & \alpha & \alpha & 39 \\ \text { cym2 } & \alpha & 57 & 54 \\ \text { cym3 } & 360 & 60 & 150 \\ \text { cym4 } & 489 & 66 & 156 \\ \text { cym5 } & 345 & 75 & 177 \\ \text { cymI1 } & 420 & 66 & 123 \\ \text { cymi2 } & 414 & 63 & 132 \\ \text { cymI5 } & 106 & 73 & 5 \mathrm{I} \\ \text { cymi8 } & \alpha & 61 & 8 \mathrm{I} \\ \text { cymi9 } & \alpha & 74 & 78\end{array}$

MM(sf), sulphur-free minimal medium; $\alpha$, generation time too long to calculate.

Protein hydrolysates and chromatography. Protein hydrolysates were prepared according to the method of Moore \& Stein (1963). Descending one- or two-dimensional chromatography involved the use of solvents A (ethanol, 2-methyl-propan-2-ol, aqueous ammonia and water) and B (2-methyl-propan-2-ol, formic acid and water) of Margolis \& Mandl(1958), and solvents $\mathrm{C}$ ( $n$-butanol, glacial acetic acid and water) and $\mathrm{D}$ ( $n$-butanol, pyridine and water) of Smith (I958). Whatman 3 MM paper was used, and was dipped in $0.2 \%$ ninhydrin in ethanol and dried at $100{ }^{\circ} \mathrm{C}$ for $5 \mathrm{~min}$ to detect the amino acid spots. The colour of these spots was stabilized by spraying with $3 \%$ cupric nitrate in ethanol.

Detection and assay of radioactivity. Radioactive spots were located on chromatographic or electrophoretic strips with a Packard radiochromatogram scanner model $\mathbf{7 2 0 0}$ (efficiency $10 \%$ ) at a scanning rate of 2 to $5 \mathrm{~cm} / \mathrm{min}$, a time constant of 10 to $100 \mathrm{~s}$ and a slit width of $2.5 \mathrm{~mm}$. Radioactivity was determined in a Nuclear Chicago 720 liquid scintillator (efficiency $60 \%$ ). The scintillating liquid contained $4.0 \mathrm{~g} \mathrm{2,5}$-diphenyloxazole and $0.12 \mathrm{~g}$ I,4-di [2-(5-phenyloxazolyl)] benzene/1 toluene.

Preparation of cell-free extracts. Overnight NB or appropriately supplemented MM cultures of bacteria were washed and resuspended in the same media, diluted I: I00 or I:40 in $500 \mathrm{ml} \mathrm{MM(sf)+djenkolic} \mathrm{acid,} \mathrm{and} \mathrm{incubated} \mathrm{with} \mathrm{aeration} \mathrm{to} \mathrm{mid} \mathrm{or} \mathrm{late} \mathrm{exponential}$ phase to give derepression of cysteine enzymes. Bacteria were sedimented at $4{ }^{\circ} \mathrm{C}$, washed in $50 \mathrm{ml}$ of $0 . \mathrm{I} \mathrm{M}$-tris- $\mathrm{HCl}$ buffer $\mathrm{pH} 8.0+0.005 \mathrm{M}$-EDTA, and resuspended in $3 \mathrm{ml}$ of the same buffer ( 30 to $60 \mathrm{mg}$ dry wt $/ \mathrm{ml}$ ), chilled and sonicated in two I $5 \mathrm{~s}$ bursts with an MSE IOO W ultrasonic disintegrator ( $\frac{3}{8}$ in probe, $8 \mu \mathrm{m}$ peak to peak). The crude extract was centrifuged at $30000 \mathrm{~g}$ for $15 \mathrm{~min}$ and the supernatant kept in ice for enzyme assays. The method of Lowry et al. (195I) was used for protein determinations.

Enzyme assays. The method of Pasternak (I962) was used for 3'-phospho-adenosine 5'sulphatophosphate (PAPS) synthetase, that of Ellis (1964) or Dreyfuss \& Monty (1963) for sulphite reductase, and the filter method of Hulanicka (1972) for sulphate permease. 

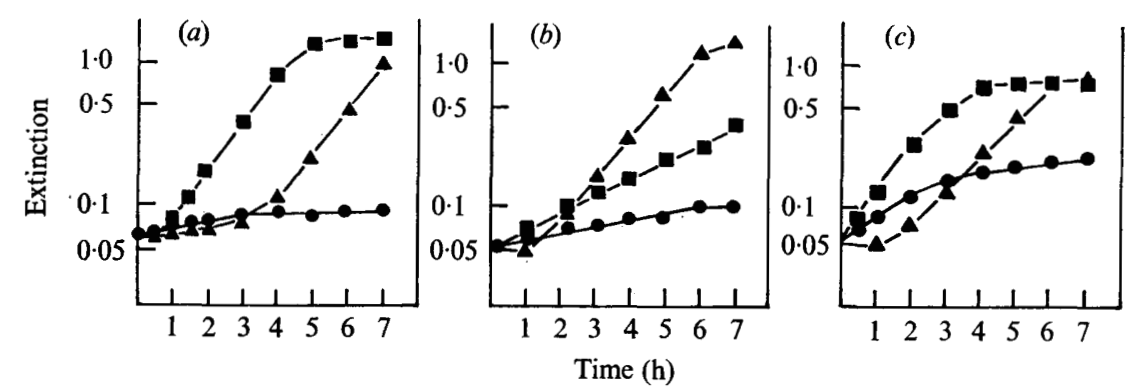

Fig. 3. Growth curves of cym mutants in sulphur-free minimal medium at $37^{\circ} \mathrm{C}$ with and without added cysteine or methionine. $-\mathrm{MM}(\mathrm{sf}) ; \boldsymbol{\Lambda}, \mathrm{MM}(\mathrm{sf})+$ cysteine; $\mathbf{\square}, \mathrm{MM}(\mathrm{sf})+$ methionine. (a) Cym2, (b) cym3, (c) cymis.

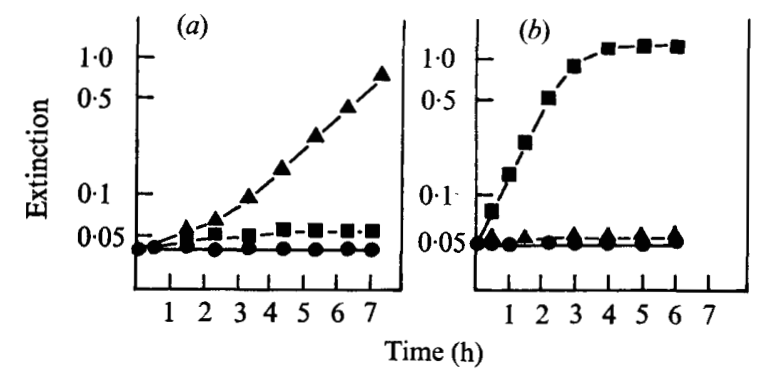

Fig. 4. Growth curves of a cysteine and a methionine mutant in sulphur-free minimal medium at $37^{\circ} \mathrm{C}$ with and without added cysteine or methionine. Symbols as in Fig. 3. (a) cysCD5I9, (b) metF96.

\section{RESULTS}

\section{Isolation of cysteine or methionine (cym) mutants}

All I9 mutants (Table I A) were either spontaneous or induced with NTG, 2-aminopurine (2AP), 5-bromouracil (5BU) or ultraviolet irradiation. Of 70 stable methionine auxotrophs induced with NTG, four (cymI-4 inclusive) grew equally well on MA+cysteine or methionine. The other 15 similar mutants (cym5-19) were identified amongst 28 cysteine (cys) mutants reported also to utilize methionine which were obtained from Dr K. E. Sanderson, Department of Biology, University of Calgary, Alberta, Canada. Eight mutants (cym2, 3, $4,6,7,8,15$ and 19) were temperature-sensitive (ts).

The homogeneity of all mutant cultures was tested by spreading dilutions of overnight NB cultures of each mutant on to NA, incubating overnight and testing each of 25 randomly chosen single colonies for their growth responses to cysteine and methionine. Bacteria from all colonies of each cym mutant grew equally well on both amino acids, making it unlikely the cym phenotype resulted from mixtures of cysteine (cys) and methionine (met) mutants.

\section{Growth characteristics in liquid culture}

It was desirable to establish more firmly the phenotype of the cym mutants and to distinguish them from cys and met mutants. The growth responses and generation times of 9 cym mutants (cym2, 3, 4, 5, I I, I 2, I5, I8 and 19) during 6 to $7 \mathrm{~h}$ incubation in MM(sf) at $37{ }^{\circ} \mathrm{C}$ were compared with those of $c y s C D_{519}$ and metF96 mutants grown under similar conditions. From the generation times of all the mutants (Table 2), and the growth response 
curves of representative cym mutants 2, 3 and 15 (Fig. 3) and cysCD5I9 and metF96 (Fig. 4) it can be seen that:

(I) There is always a lag of $\mathrm{I}$ to $3 \mathrm{~h}$ in growth response to cysteine but no lag with respect to methionine. Cysteine inhibits the growth of wild type in $M M(s f)$ for about the same time as this lag (Qureshi, I97I). It may be that cysteine similarly affects cym mutants by, for example, inhibiting either the release of repression of dihydro-orotic acid dehydrogenase (Tonomura \& Novelli, 1960), the activity of homoserine dehydrogenase (Datta, 1967), the synthesis of leucine, isoleucine, valine and threonine (Nagy, Kari \& Hernádi, 1969), or catalase and respiratory chain function (Bhuvaneswaran, Sreenivasan \& Rege, 1964).

(2) All cym mutants are clearly different from cysCD519 and metF96 in that they respond to both cysteine and methionine instead of one of these compounds.

(3) Growth response patterns and leakiness vary between cym mutants but three basic types are recognizable (Table 2): (i) cym2, I 8 and 19 - similar response to cysteine and methionine, not leaky (Fig. 3a); (ii) cym3, 4, 5, I I and I 2 - better growth response to cysteine than to methionine, slightly leaky (Fig. $3 b$ ); (iii) cymi $5-$ similar growth response to both cysteine and methionine, leaky (Fig. $3 c$ ).

\section{Growth responses to cysteine and methionine precursors}

To clarify the phenotype of the cym mutants, their growth responses on MA+ either sulphite, thiosulphate (high and low concentration), sulphide, cysteine, cystathionine, homocysteine, vitamin $\mathbf{B}_{12}$ or methionine were compared with wild type at both 37 and $25{ }^{\circ} \mathrm{C}$. At $37^{\circ} \mathrm{C}$ all cym mutants responded equally well to thiosulphate, sulphide, cysteine, cystathionine, homocysteine and methionine. None grew on vitamin $\mathrm{B}_{12}$. In contrast, incubation at $25{ }^{\circ} \mathrm{C}$ resulted in much heterogeneity and no clear pattern of growth response amongst the II mutants which were not ts.

In similar experiments in $\mathrm{MM}$ at $37^{\circ} \mathrm{C}$, care was taken to ensure the stability of the sulphur-containing compounds used (Postgate, 1963). Fresh solutions of sulphite, thiosulphate and sulphide were always used. Supplemented liquid minimal media with and without bacteria were incubated for the full period of the experiments, after which retention of $\mathrm{pH}$ values $7 \cdot 0$ to $7 \cdot 3$ was shown, and the presence of each of the inorganic salts confirmed by the quantitative methods of Feigl (1947). As additional controls the cultures of single representative cys and met mutants, each with different patterns of growth responses to either the cysteine or the methionine precursors, were included. All of the cys and met mutants gave growth responses in accordance with their phenotypes. The cym mutants behaved as in the solid media experiments except that: (i) only seven mutants (cym5, 6, 8, I5, I6, I7 and I8) failed to grow on sulphite whereas the remaining I 2 grew well; (ii) growth responses to thiosulphate were variable, particularly at the lower concentration, both between mutants and between experiments (an unreliability also encountered by Hockenhull, 1949).

The only conclusion permissible is that some cym mutants appear to be blocked before sulphite on the cysteine pathway (Fig. I) and may be deficient in the $c y s C, D$, or $H$ gene products and others after it with probable deficiencies in the $c y s I, J$ or $G$ products. If this is so, are cym mutants different from comparable cys mutants? For example, could their growth responses to methionine and its precursors be due to highly efficient utilization of small amounts of cysteine present as impurities in these compounds? To test this, the growth responses in liquid culture of cym2 and cys $C 700$ mutants to cysteine, cystathionine, homocysteine and methionine, each at concentrations of $0.05,0.5, \mathrm{I} \cdot 0,5.0$ and $\mathrm{I} 0 \mu \mathrm{g} / \mathrm{ml}$, were compared. As a control, the metAI 5 mutant which is able to utilize both cystathionine 
and homocysteine, was included. The minimum concentration of cysteine to support the maximum growth of both cym2 and cys $C_{700}$ mutants was the same (IO $\left.\mu \mathrm{g} / \mathrm{ml}\right)$. The same concentrations of methionine $(5 \mu \mathrm{g} / \mathrm{ml})$ and cystathionine and homocysteine $(10 \mu \mathrm{g} / \mathrm{ml})$ elicited maximum growth responses from both cym2 and metA 1 5. cysC70o failed to respond to methionine and its precursors and $m e t A I 5$ to cysteine at any concentration. Thus cym2 did not utilize cysteine more efficiently than the $c y s C 700$ mutants. Its growth response pattern to methionine precursors was the same as metAI5 and there was no evidence of cysteine impurities in these precursors. The growth distinction between the cym phenotype and those of similar cys or met mutants was upheld.

\section{Linkage and complementation analysis of cym mutants}

The similar phenotypes of the cym mutants and their apparent relationship to the clustered cys $C$ and $D$ or $G, I$ and $J$ genes suggested that some or all cym mutants could be closely linked to each other and possibly possess similar functional deficiencies. In a series of reciprocal spot transduction experiments between all cym mutants selecting wild-type recombinants on MA using wild-type donor phage as a standard, the relative frequency of complete transductants and the presence or absence of abortive transductants (complementation) between cym mutants was determined. A yield of 60 to 200 recombinants/spot was assumed to indicate no linkage and o to 6o/spot to reflect linkage. Failure to recombine (an indication of identical site mutation or a deletion) or lack of complementation in a cross was checked by repeating the cross three times in both directions.

On the basis of recombination frequencies the cym mutants fell into four groups, A, B, C and $\mathrm{D}$, with low frequencies of recombination between members of the same group and a high frequency between members of different groups. All mutants within groups recombined with each other. Within groups B and C, subgroups were apparent in which o to 30 (often $<$ I5) recombinants per spot were obtained; there were three cymB subgroups ( $a, b$ and $c$ ), and two cymC subgroups ( $a$ and $b$ ). The cym mutants in these groups and subgroups and the complementation patterns within them were: cymA (I, 2, 7, I3 and I9) - I and 2, 2 and I9, and 13 and 19 failed to complement but all other combinations did, so that no clear pattern emerged; cymBa $(3,4), b(5,8$ and 16$)$ and c $(6,15$ and 18$)$ - mutants within subgroups a and $\mathrm{c}$ failed to complement each other but those of group b did, and complementation always occurred between mutants of different subgroups; cymCa (I2, I4) and b (9, I0, II) - there was no complementation between mutants of the same subgroup but it did occur between those of different subgroups; cymD (I7) - this mutant complemented all other cym mutants.

\section{Map locations}

The results of preliminary conjugation experiments with five different $\mathrm{Hfr}$ strains (Qureshi, 1968) indicated that cymA and B mutations were located between 50 and $100 \mathrm{~min}$, cymC between 50 and $80 \mathrm{~min}$, and cymD elsewhere - probably beyond $100 \mathrm{~min}$ (Fig. 2).

The cysC,D,H,I,J cluster of genes (Fig. 2) is located at $90 \mathrm{~min}$ and as cymA and B mutants resembled mutants of these genes phenotypically, the frequency of recombination in crosses involving representative cys and cym mutants was compared with that obtained with the wild-type donor in a series of spot transduction experiments. Recombination to prototrophy between cymA and cys $C$ and $D, \operatorname{cymBa}$ and $c y s H$, cymBb and $c y s J$, and cymBc and cys $I$ was never greater than $10 \%$ of that with the wild-type marker, indicating linkage in each case. Linkage of cymC mutant with cys $A(88 \mathrm{~min})$ was similarly established and cymD 
Table 3. Cotransduction of cym and cys mutants

\begin{tabular}{|c|c|c|c|c|c|}
\hline Donor & Recipient & $\begin{array}{c}\text { Cotransduction } \\
(\%)\end{array}$ & Donor & Recipient & $\begin{array}{c}\text { Cotransduction } \\
(\%)\end{array}$ \\
\hline \multirow[t]{4}{*}{ cymA2 } & $\begin{array}{l}\text { cysC.523 } \\
\text { cysC218 }\end{array}$ & $\begin{array}{l}57.4 \\
96.6\end{array}$ & cymBb8 & $\begin{array}{l}\text { cysJ } 299 \\
\text { cys } 168\end{array}$ & $\begin{array}{l}92 \\
88 \cdot 5\end{array}$ \\
\hline & cysC $C_{7} 00$ & $94 \cdot 2$ & & & \\
\hline & cysD220 & $97 \cdot 8$ & cymBc6 & cysI295 & 93 \\
\hline & cysD505 & $79 \cdot \mathrm{I}$ & & cysJ299 & 73 \\
\hline \multirow[t]{3}{*}{ cymBa4 } & cysHI82 & $96 \cdot 5$ & cymCaI 2 & cysA69 & $25 \cdot 9$ \\
\hline & cysI5I & 92.0 & cymCbI I & cys $A 69$ & $70 \cdot 4$ \\
\hline & cysJ447 & $68 \cdot 6$ & cymDi 7 & cysG439 & $92 \cdot 5$ \\
\hline
\end{tabular}

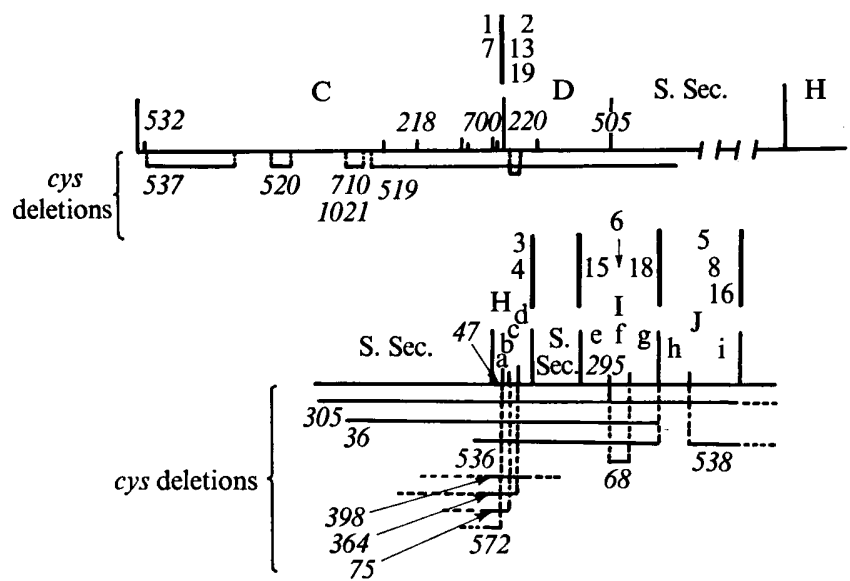

Fig. 5. Map location of cymA, $\mathrm{Ba}, \mathrm{Bb}$ and $\mathrm{Bc}$ mutants in the cysCDHIJ region of Salmonella typhimurium (after Demerec et al. I963). Cym mutants are in roman type. S. Sec., silent section.

mutants also yielded few recombinants with both $\operatorname{cys} E$ and $G$ mutants located at I Io to I 7 min (see Fig. 2).

More precise mapping of cym mutants was achieved by measuring cotransduction with the various cys mutants. Optimum conditions for the detection of colonies with the cym donor phenotype of a growth response to methionine were first established and then large numbers of cotransduction crosses carried out. Never less than 150 and often more than Iooo recombinants were screened from each cross. Individual mutants within cym groups $\mathrm{A}$ and $\mathrm{D}$ and the subgroups of groups $\mathrm{B}$ and $\mathrm{C}$ gave similar cotransduction frequencies, so that only data for representative donors are recorded (Table 3). Thus cymA mutants are close to the junction of the cys $C$ and $D$ genes (Fig. 5), and cymBa mutants are confirmed as being closest to $c y s H$ or $I$, as are cymBb to cys $J$ and cymBc to cys $I$. CymC linkage to cys $A$ is also confirmed, although the lesions in cym $\mathrm{Cb}$ mutants are closer to cys $A 69$ than cym $\mathrm{Ca}$. Linkage of cymD to $c y s G$ was clearly indicated; there was no cotransduction with $c y s E$.

Finally, some additional information emerged from a series of reciprocal spot transduction crosses between relevant cym mutants and deletions of the cys $C, D, H, I, J$ and $A$ genes. There was recombination between all five cymA mutants and cys $C$ deletions 537, 520 and $7 I 0$, but not with cysCD5I9 (Fig. 5), a result compatible with their location at the right end of the cysC gene or the left end of $c y s D$. On the basis of the recombination profiles of cymB mutants with cys deleted mutants (Table 4) it is concluded that: (i) both cymBa mutants are 
Table 4. Recombination between cymB mutants and cys deletions

\begin{tabular}{|c|c|c|c|c|c|c|c|c|}
\hline \multirow[b]{2}{*}{ Cym mutants } & \multicolumn{8}{|c|}{ cys deletions } \\
\hline & $D_{305}$ & $H_{3} 6$ & $H_{5} 3_{3} 6$ & $H_{398}$ & $H_{364}$ & $\mathrm{H}_{572}$ & 168 & $J_{538}$ \\
\hline cymBa3 and 4 & - & - & - & + & + & + & + & + \\
\hline cymBb5, 8 and 16 & - & + & + & + & + & + & + & - \\
\hline cymBbi 8 & - & + & - & + & + & + & + & + \\
\hline cymBc6 & - & - & - & + & + & + & - & + \\
\hline cymBcI 5 & - & - & - & + & + & + & + & + \\
\hline
\end{tabular}

likely to be located at the right end of $c y s H$ (or possibly in the adjacent silent section); (ii) cymBb5, 8 and 16 are probably at the right end of $c y s J$, but as cysBbr8 recombines with cysJ 538 and fails to recombine with cysHI $_{536}$, it is likely to be at the left end of cysJ or right end of cysI; (iii) both cymBc mutants are obviously located in the cys $H I$ region with cymBc6 within the middle region of the cysI gene covered by cysI68.

None of the cymCa or $\mathrm{b}$ mutations recombined with the two deletions cysA2o and 533 thought to cover the whole cysA gene (Demerec, Gillespie \& Mizobuchi, I963; Dreyfuss, 1964), suggesting their location within it.

\section{Functional deficiencies}

Since each cym mutant was located within or close to a cys gene, it was of interest to determine whether the difference in phenotype between the mutants was associated with possession of the same or different functional deficiencies. This promoted a series of complementation tests and enzyme assays.

Complementation between cym and cys mutants. The spot transduction method was used and the criteria of lack of complementation between any pair of mutants were the same as those used previously. In reciprocal crosses between the five cymA, ten $c y s C$ and five $c y s D$ mutants it first became apparent that, in contrast to the results of Mizobuchi, Demerec \& Gillespie (1962), cysC mutants fell clearly into two complementation groups. Furthermore, not only did two cymA mutants (AI and 7-subgroup a) complement all cys $D$ mutants and three (2, I3 and 19 - subgroup b) fail to complement $c y s D$ mutants, but cymAa also complemented one group of the cysC mutants but not the other. It was concluded that cymAa mutants had the same defect as some cys $D$ mutants and cymAb mutants the same defect as all cys $D$ mutants tested.

Similar reciprocal crosses between four cys $H$, three $c y s I$, three cys $J$, and all cymBa, B, and $\mathrm{C}$ mutants were carried out. In accordance with Demerec et al. (1963), no complementation between cys mutants of the same group occurred. There was also no complementation between both cymBa mutants and all cys $H$ mutants, all cymBb mutants (except cymBbi 8 ) and the cysJ mutants, and both cymBc (and cymBbi 8 ) and cysI mutants. Abortive transductants were detected in all other crosses. Thus cymBa and cys $H$ mutants had the same functional defect as did all cymBc, cymBbi 8 and cysI mutants, and four cymBb and cys $J$ mutants. It was interesting that cymBbi 8 also mapped away from the other three cymBb mutants. Mizobuchi et al. (I962) reported the existence of three cys $A$ cistrons $a, b$ and $c$. The similarity between cymCa and $\mathrm{b}$ and cys $A a, b$ and $c$ defects was tested in further reciprocal crosses between cysAa20I, Ab2r, Ac22, Acr97 and Ac35I, and all five cymC mutants. The distinction between $c y s A a$ and $A b$ was not sustained in that no complementation occurred between the representative mutants, but whereas cymCb complemented all cys $A$ mutants, cymCa only complemented cys $A c$ mutants. It can thus be stated that both 
Table 5. Enzyme deficiencies of cym mutants

Growth of all mutants was in $\mathrm{MM}(\mathrm{sf})+$ djenkolic acid.

A. PAPS-synthetase and sulphite reductase activities in the supernatant fraction of cymA, $\mathrm{Ba}, \mathrm{Bb}$ and $\mathrm{D}$ mutants

\begin{tabular}{|c|c|c|c|c|}
\hline \multirow[b]{2}{*}{ Strains } & \multicolumn{2}{|c|}{ PAPS synthetase } & \multicolumn{2}{|c|}{ Sulphite reductase } \\
\hline & $\begin{array}{c}\text { Specific } \\
\text { activity } \\
\text { (nmol } / \mathrm{mg} \\
\text { protein } / \mathrm{min} \text { ) }\end{array}$ & $\begin{array}{l}\text { Relative } \\
\text { specific } \\
\text { activity }\end{array}$ & $\begin{array}{c}\text { Specific } \\
\text { activity } \\
\text { (nmol/mg } \\
\text { protein } / \mathrm{min})\end{array}$ & $\begin{array}{l}\text { Relative } \\
\text { specific } \\
\text { activity }\end{array}$ \\
\hline Wild type & $199 \cdot 7$ & 100 & $13 \cdot 3$ & 100 \\
\hline cymAa I & 0 & 0 & $8 \cdot 7$ & $65 \cdot 6$ \\
\hline cymAb2 & 0 & 0 & 10.4 & $78 \cdot I$ \\
\hline cymAa7 & 0 & 0 & I I $\cdot 2$ & $84 \cdot 2$ \\
\hline cymAbig & 0 & 0 & $21 \cdot 5$ & $16 I \cdot 6$ \\
\hline cysCrozI* & $188 \cdot 8$ & 94.5 & $14 \%$ & $108 \cdot 2$ \\
\hline cysD220 & 0 & 0 & II.9 & $89 \cdot 4$ \\
\hline Wild type & $104 \cdot 0$ & 100 & 25.4 & 100 \\
\hline cymBa3 & $\mathrm{I} 8 \mathrm{I} \cdot 2$ & $174 \cdot 2$ & $25 \cdot 9$ & IOI 9 \\
\hline cymBa4 & $337 \cdot 5$ & $324 \cdot 5$ & $34 \cdot 5$ & 135.8 \\
\hline cysH 75 & $104 \cdot 0$ & 100 & $19 \cdot 7$ & $77 \cdot 5$ \\
\hline Wild type & $144^{\circ} \mathrm{O}$ & 100 & $27 \cdot 8$ & 100 \\
\hline cymBb5 & $327 \cdot 9$ & $227 \cdot 7$ & 0 & 0 \\
\hline cymBb8 & $374 \cdot 9$ & $26 \cdot 03$ & 0 & 0 \\
\hline cymBbi 6 & $828 \cdot 9$ & $575 \cdot 6$ & 0 & 0 \\
\hline cymBbr 8 & $820 \cdot 9$ & $570 \cdot 6$ & 0 & 0 \\
\hline cysJ299 & $101 \cdot 4$ & $70 \cdot 4$ & 0 & 0 \\
\hline Wild type & $87 \cdot 5$ & 100 & $3 I \cdot 5$ & 100 \\
\hline cymBc6 & $47 \mathrm{I} \cdot 5$ & $538 \cdot 8$ & 0.25 & 0.79 \\
\hline cymBcI 5 & $108 \cdot 1$ & 123.5 & 0 & 0 \\
\hline cysII 295 & $256 \cdot 9$ & $293 \cdot 6$ & 0.80 & $2 \cdot 5 \mathrm{I}$ \\
\hline Wild type† & NT & NT & 42 & 100 \\
\hline cymDi $7 \dagger$ & NT & NT & 0 & o \\
\hline cysG439† & NT & NT & 0 & 0 \\
\hline
\end{tabular}

B. Sulphate permease activity in cymCa and $\mathrm{Cb}$ mutants

* APS not PAPS made.

$\begin{array}{lcc} & \begin{array}{c}\text { Specific } \\ \text { activity } \\ \text { (pmol/min/ } \\ \text { mg dry wt) }\end{array} & \begin{array}{c}\text { Relativ } \\ \text { specifi } \\ \text { activit }\end{array} \\ \text { Wild type } & \text { I } 67 & \text { I00 } \\ \text { cymCaI2 } & 3.3 & 2.0 \\ \text { cymCaI4 } & 3.0 & 1 \cdot 8 \\ \text { cymCb9 } & 0.3 & 0.2 \\ \text { cymCbI0 } & 3.7 & 2.2 \\ \text { cymCbI I } & 4.85 & 2.9 \\ \text { cys A20 } & 2.5 & 1.5 \\ \text { cys A2I } & 9.3 & 5.6\end{array}$

$\uparrow$ Sulphite reductase assay by the rate of sulphite-dependent NADPH oxidation (Dreyfuss \& Monty, 1963), instead of by sulphide formation (Ellis, 1964) as for all other strains.

NT, Not tested. 
Table 6. Summary of relationships between cym and cys mutants

\begin{tabular}{|c|c|c|c|c|c|}
\hline $\begin{array}{l}\text { Group and } \\
\text { subgroup }\end{array}$ & $\begin{array}{c}\text { Mutant } \\
\text { numbers }\end{array}$ & $\begin{array}{l}\text { Basis of } \\
\text { subgroups }\end{array}$ & $\begin{array}{c}\text { Map } \\
\text { location }\end{array}$ & $\begin{array}{c}\text { Enzyme } \\
\text { deficiencies }\end{array}$ & $\begin{array}{l}\text { cys mutant } \\
\text { similarity }\end{array}$ \\
\hline $\begin{array}{l}\text { cymAa } \\
\text { cymAb }\end{array}$ & $\begin{array}{l}1,7 \\
2,13,19\end{array}$ & $\begin{array}{l}\text { No complementa- } \\
\text { tion with cysC or } \\
D \text { mutants }\end{array}$ & $\begin{array}{l}\text { cys } C \text { and } \\
D \text { junction }\end{array}$ & $\begin{array}{l}\text { PAPS } \\
\text { synthetase }\end{array}$ & $\begin{array}{l}\text { cys } C \\
\text { cys } D\end{array}$ \\
\hline cymBa & 3,4 & $\begin{array}{l}\text { Recombination and } \\
\text { complementation }\end{array}$ & $\begin{array}{l}\text { Within } \\
\text { cys } H\end{array}$ & $\begin{array}{l}\text { Sulphite } \\
\text { reductase }\end{array}$ & cys $H$ \\
\hline cymBb & 5,8, I $6,18^{*}$ & $\begin{array}{l}\text { Recombination and } \\
\text { complementation }\end{array}$ & $\begin{array}{l}\text { Within } \\
\text { cysI }\end{array}$ & $\begin{array}{l}\text { Sulphite } \\
\text { reductase }\end{array}$ & cys $I$ \\
\hline cymBc & 6,15 & $\begin{array}{l}\text { Recombination and } \\
\text { complementation }\end{array}$ & $\begin{array}{l}\text { Within } \\
\text { cysJ }\end{array}$ & $\begin{array}{l}\text { Sulphite } \\
\text { reductase }\end{array}$ & cys $J$ \\
\hline $\begin{array}{l}\text { cymCa } \\
\text { cymCb }\end{array}$ & $\begin{array}{l}\mathrm{I} 2,14 \\
9,10,11 \mathrm{~V}\end{array}$ & $\begin{array}{l}\text { Recombination and } \\
\text { complementation } \\
\text { with cys } A \text { mutants }\end{array}$ & $\begin{array}{l}\text { Within } \\
\text { cys } A\end{array}$ & $\begin{array}{l}\text { Sulphate } \\
\text { permease }\end{array}$ & cys $A$ \\
\hline cymD & 17 & & $\begin{array}{l}\text { Within or } \\
\text { close to } \text { cys } G\end{array}$ & $\begin{array}{l}\text { Sulphite } \\
\text { reductase }\end{array}$ & cys $G$ \\
\hline
\end{tabular}

cymCa and $\mathrm{b}$ mutants have a different functional deficiency from $c y s A c$ mutants and that cym $\mathrm{Cb}$ are also functionally different from cys $A a$ or $b$ mutants.

Enzyme deficiencies of cym mutants. CymA, B and D mutants were likely to have deficiencies in cysteine biosynthesis at some stage in the conversion of intracellular sulphate to sulphide (Fig. I), and cymC mutants in the uptake of sulphate. Thus assays of the activities of PAPS synthetase (the product of $c y s C$ and $D$ ) and sulphite reductase (cys $I, J$ and $G$ ) in cymAa and $\mathrm{b}, \mathrm{Ba}, \mathrm{b}$ and $\mathrm{c}$, and cymD strains, and of sulphate permease (cys $A$ ) in cymCa and $b$ mutants were carried out. The cym mutants were assayed group by group together with wild type and relevant cys mutants in duplicate. All bacteria were grown in sulphurfree minimal medium [MA(sf)]+djenkolic acid to ensure derepression. For cymA and B mutants the sulphite reductase assay used was that of Ellis (1964). Later, and exclusively for the cymD mutant, the more sensitive assay of Dreyfuss \& Monty (1963) was used.

From Table 5, all cymA mutants completely lack PAPS synthetase like cys $D$ mutants; mutants cymBb, cymBc and cymD lack or have much reduced levels of sulphite reductase like cys $J, I$ and $G$ mutants respectively, and cymC mutants have reduced levels of sulphate permease like cysA mutants. There is no evidence that cym mutants possess leaky deficiencies for $c y s$ enzymes. The elevated levels of PAPS synthetase in cymBa, $\mathrm{Bb}$ and $\mathrm{Bc}$ mutants lacking sulphite reductase could be due to derepression, even super-derepression, in the absence of cysteine (Dreyfuss, 1964; Pardee \& Prestidge, 1966; Dreyfuss \& Monty, I963) and induction by non-utilized $O$-acetylserine (Jones-Mortimer, I968), but it is strange that derepression of sulphite reductase does not occur in cymA mutants lacking PAPS synthetase, for similar intracellular levels of cysteine and $O$-acetylserine would be anticipated.

\section{The nature of cym mutants}

From a summary of all the results described so far (Table 6) the very close similarity between cym and cys mutants is apparent. To all intents cym mutants are cys mutants, except that they are able to use methionine and its precursors for growth whereas cys 'mutants cannot. The rest of this paper is concerned with attempts to explain this difference.

Possible interconversion of methionine and cysteine. As long ago as 1947, Lampen, Roepke 
and Jones reported the growth of a sulphite-less mutant of $E$. coli on methionine as its sole source of sulphur. Also, growth of Torulopsis utilis in the presence of exogenous $\left[{ }^{35} \mathrm{~S}\right]-$ methionine resulted in the appearance of intracellular $\left[{ }^{35} \mathrm{~S}\right]$ cysteine (Roberts et al. 1955 ), and the breakdown of the methionine precursor, cystathionine, in various fungi by cystathionine$\gamma$-synthethase (which normally catalyses its synthesis from cysteine) in the absence of cysteine has been reported (Flavin, Delavier-Klutchko \& Slaughter, I964; DelavierKlutchko \& Flavin, 1965). These results all support the conversion of methionine tocysteine in these organisms. Could such a conversion be occurring in cym mutants of $S$. typhimurium? If so, then the radioactivity of $\left[{ }^{35} \mathrm{~S}\right] \mathrm{methionine}$ in their growth medium should be incorporated into the cysteine of their protein.

Exponential-phase cultures of cymAai, Ab2, Ba4, Bbi8, Bci5, $\mathrm{Ca}$ I2, $\mathrm{Cb}$ I I and $\mathrm{Di} 7$ mutants and of wild type in $\mathrm{MM}+$ methionine were transferred to $\mathrm{MM}(\mathrm{sf})+\left[{ }^{35} \mathrm{~S}\right]$ methionine, incubation was continued for $4 \mathrm{~h}$ and protein hydrolysates were made. All preparations were subjected to two- and one-dimensional chromatography using solvents $\mathrm{A}, \mathrm{B}, \mathrm{C}$ and $\mathrm{D}$. Only one radioactive spot was seen after two-way descending chromatography using either solvents A or B, so all four solvents were used for one-way descending chromatography, the chromatograms cut into a number of strips $5 \mathrm{~cm}$ wide and the radioactive spots detected with a radiochromatogram scanner. The R-proline of the spots for solvents $\mathrm{A}$ and $\mathrm{B}$ and the $R_{F}$ values of the same spot for C and D were then calculated.

All the radioactive spots were associated with methinoine sulphone (R-proline 0.69 to 0.72 and 0.45 to 0.48 , in solvents $\mathrm{A}$ and $\mathrm{B} ; \boldsymbol{R}_{F} 0.22$ to 0.23 and $0.3 \mathrm{I}$ to 0.32 , in solvents $\mathrm{C}$ and $\mathrm{D}$ ). To confirm this, all spots were eluted and re-chromatographed; the same $R_{F}$ values were obtained. Although a spot equivalent to cysteic acid was always detected from all extracts following development with ninhydrin and preservation with copper nitrate solution, it was never radioactive. Methionine appeared not to be converted to cysteine by cym mutants via a reversal of the synthesis of cystathionine from $O$-succinylhomoserine.

Requirement for the activity of cysteine enzymes in cym mutants responding to methionine. If in the presence of methionine normal synthesis of cysteine from inorganic sulphur occurs (Fig. I), involvement of sulphate activating and reducing enzymes is implied, perhaps utilizing small amounts of sulphate impurity in MM(sf). ATP sulphurylase is specifically inhibited by selenate (Wilson \& Bandurski, I958; Hilz, Kittler \& Knape, I959; Pasternak, 1962), so that if activity of this enzyme in cym mutants is required for their growth response to methionine, then methionine should not reverse inhibition by selenate. The cell yields, by weight, of wild type, cysCD519 and metF96 mutants were compared with those of ten representative cym mutants after $7 \mathrm{~h}$ growth on $\mathrm{MM}(\mathrm{sf}), \mathrm{MM}(\mathrm{sf})+$ cysteine and $\mathrm{MM}(\mathrm{sf})+$ methionine in the presence or absence of 2 mM-selenate. Wild-type responses were also measured in MM, which contains sulphate (Table 7).

Although the results varied between strains in terms of individual growth responses to cysteine or methionine, they were consistent with previous data (Figs. 3 and 4, and Table 2) and indicated clearly that for all strains cysteine reversed inhibition by selenate but that methionine did not. The possibility that methionine + selenate formed an inhibitory complex with a different effect from selenate alone was excluded when the growth response of wild type in $\mathrm{MM}(\mathrm{sf})+$ cysteine was shown to be virtually unaffected by the addition of methionine + selenate early in the exponential phase. Thus non-reversal of the methionine biosynthetic pathway in cym mutants is upheld, and their requirement for activity of their cysteine biosynthetic enzymes in the presence of methionine substantiated.

In vivo stimulation by methionine of cysteine enzyme activities in cym mutants. Cysteine enzyme activity in cym mutants presumably involved uptake and activation of sulphate 
Table 7. Increase in mass of wild type, cym mutants and other auxotrophs after growth in sulphur-free minimal medium with and without cysteine or methionine and in the presence or absence of selenate $(2 \mathrm{~mm})$

\begin{tabular}{|c|c|c|c|c|c|c|}
\hline & \multicolumn{6}{|c|}{ Increase in weight* ( $\mathrm{mg}$ dry $\mathrm{wt} / \mathrm{ml}$ cells) } \\
\hline & \multicolumn{2}{|c|}{$\mathrm{MM}(\mathrm{sf})$} & \multicolumn{2}{|c|}{$\mathrm{MM}(\mathrm{sf})+$ cysteine } & \multicolumn{2}{|c|}{ MM(sf) + methionine } \\
\hline & $\begin{array}{c}\text { Selenate } \\
\text { absent }\end{array}$ & $\begin{array}{c}\text { Selenate } \\
\text { present }\end{array}$ & $\begin{array}{c}\text { Selenate } \\
\text { absent }\end{array}$ & $\begin{array}{c}\text { Selenate } \\
\text { present }\end{array}$ & $\begin{array}{l}\text { Selenate } \\
\text { absent }\end{array}$ & $\begin{array}{c}\text { Selenate } \\
\text { present }\end{array}$ \\
\hline Wild type & 0.125 & 0.0007 & 0.650 & 0.315 & 0.460 & 0.010 \\
\hline Wild type $\dagger$ & 0.725 & 0.015 & 0.650 & $0 \cdot 280$ & 0.725 & 0.017 \\
\hline cymA2 & 0.010 & 0.005 & 0.325 & 0.237 & 0.500 & 0.010 \\
\hline cymAig & 0.007 & 0 & 0.112 & 0.232 & 0.360 & 0.010 \\
\hline cymBa3 & 0.017 & 0.010 & 0.505 & 0.275 & $0 \cdot 112$ & 0.012 \\
\hline cymBa4 & 0.012 & 0.004 & 0.460 & $0 \cdot 277$ & 0.107 & 0.009 \\
\hline cymBb5 & 0.023 & 0.010 & 0.193 & 0.205 & 0.083 & 0.016 \\
\hline cymBbi 8 & 0.009 & 0.005 & 0.316 & 0.242 & 0.184 & 0.007 \\
\hline cymBc6 & 0.062 & 0.007 & $0 \cdot 112$ & 0.305 & 0.307 & 0.012 \\
\hline cymBci 5 & 0.065 & 0.010 & 0.328 & 0.430 & 0.278 & 0.015 \\
\hline cymCaI 2 & 0.015 & 0.005 & 0.273 & 0.280 & 0.178 & 0.007 \\
\hline cymCbI I & 0.016 & 0.003 & 0.204 & 0.233 & $0.18 \mathrm{I}$ & 0.010 \\
\hline $\operatorname{cys} C D_{519}$ & 0.015 & 0 & 0.225 & 0.152 & $0.02 \mathrm{I}$ & 0.007 \\
\hline metF96 & 0 & 0.004 & 0.004 & 0.004 & 0.469 & 0.014 \\
\hline
\end{tabular}

present as an impurity in $\mathrm{MM}(\mathrm{sf})$ which must in some way be stimulated by methionine.

Could the cysteine enzymes of cym mutants still be functioning in vivo in the presence of methionine? If so, it should be possible to stimulate with methionine the incorporation of radioactivity from extracellular ${ }^{35} \mathrm{SO}_{4}{ }^{2-}$ into protein. Exponential-phase cultures of wild type and cymA2 grown in $\mathrm{MM}+$ methionine were washed twice in $\mathrm{MM}(\mathrm{sf})$ medium and transferred to $\mathrm{MM}(\mathrm{sf})+{ }^{35} \mathrm{SO}_{4}{ }^{2-}(0.85 \mathrm{mM} ; 0.2 \mu \mathrm{Ci} / \mathrm{ml})$ in either the presence or absence of methionine, and incubation was continued for $3 \mathrm{~h}$. Some samples were collected on Millipore filters, with a layer of Celite (Dreyfuss, 1964), either directly or after treatment with $50 \% \mathrm{TCA}$ in $\mathrm{MM}(\mathrm{sf})+\mathrm{SO}_{4}{ }^{2-}$, and washed with either $\mathrm{MM}(\mathrm{sf})+\mathrm{SO}_{4}{ }^{2-}$ or $5 \% \mathrm{TCA}$ in $\mathrm{MM}(\mathrm{sf})+\mathrm{SO}_{4}{ }^{2-}$ as appropriate, before their radioactivity was measured. Other samples were treated with $50 \%$ TCA, washed twice in $5 \%$ TCA, the protein contents oxidized (Margolis \& Mandl, I958) overnight and hydrolysates subjected to one-way descending chromatography in solvent $\mathrm{C}$.

As the amount of radioactivity in whole cells and TCA-insoluble fractions 'of iwild' type and cymA2 bacteria grown in the presence of methionine were almost the same (Table 8), methionine enabled the cym mutant to utilize exogenous sulphate for growth. In addition, the chromatograms of extracts of wild type growing in $\mathrm{MM}(\mathrm{sf})+{ }^{35} \mathrm{SO}_{4}{ }^{2-}$ without methionine gave two radioactive spots corresponding to cysteic acid and methionine sulphone, the oxidized forms of cysteine and methionine respectively. By contrast, extracts of both wild type and cymA2 grown in the presence of methionine gave one spot corresponding to cysteic acid, which is compatible with methionine stimulating intracellular reduction of sulphate to sulphide and its subsequent conversion to cysteine in cymA2.

Inhibition by triazole and the cym phenotype. 1,2,4-triazole inhibits the growth of wildtype $S$. typhimurium in MM, this effect being reversed by cysteine, methionine or serine (Hulanicka et al. 1972). These authors presented evidence that triazole interferes with the induction of the cysteine biosynthetic enzymes by $O$-acetyl serine (OAS) involving the cys $B$ 
Table 8. Amount of radioactivity incorporated from ${ }^{35} \mathrm{SO}_{4}{ }^{2-}$ into protein in wild-type and cymA2 bacteria in the presence and absence of methionine

\begin{tabular}{|c|c|c|c|}
\hline Strains & Growth media & Fractions & c.p.m./mg \\
\hline \multirow[t]{2}{*}{ Wild type } & $\mathrm{MM}(\mathrm{sf})+{ }^{35} \mathrm{SO}_{4}{ }^{2-}$ & $\begin{array}{l}\text { WC } \dagger \\
\text { TCA }\end{array}$ & $\begin{array}{l}37815 \\
31800\end{array}$ \\
\hline & $\mathrm{MM}(\mathrm{sf})+{ }^{35} \mathrm{SO}_{4}{ }^{2-}+$ methionine & $\begin{array}{l}\text { WC } \\
\text { TCA }\end{array}$ & $\begin{array}{r}13340 \\
9149\end{array}$ \\
\hline \multirow[t]{2}{*}{ cymA2 } & $\mathrm{MM}(\mathrm{sf})+{ }^{35} \mathrm{SO}_{4}{ }^{2-*}$ & $\begin{array}{l}\text { WC } \\
\text { TCA }\end{array}$ & $\begin{array}{l}5979 \\
4966\end{array}$ \\
\hline & $\mathrm{MM}(\mathrm{sf})+{ }^{35} \mathrm{SO}_{4}{ }^{2-}+$ methionine & $\begin{array}{l}\text { WC } \\
\text { TCA }\end{array}$ & $\begin{array}{r}12215 \\
9403\end{array}$ \\
\hline
\end{tabular}

gene product (Jones-Mortimer, I968). Triazole resistant $\left(\operatorname{trz} \mathrm{r}^{\mathrm{r}}\right)$ mutants have been isolated in which OAS-sulphydrylase is depleted, with a consequent elevation in intracellular OAS levels, and which possess derepressed, but repressible, levels of the sulphate activation and reduction enzymes (Hulanicka \& Klopotowski, 1972).

The effect of triazole on the wild type is similar to the effect of a cym mutation, and so it was of interest to determine the effect of trz $\mathrm{z}^{\mathrm{r}}$ mutations on the cym phenotype. Trz derivatives of the temperature-sensitive cymA2 mutant were isolated by spreading washed overnight NB cultures on to MA+triazole ( $10 \mathrm{mM}$ ), incubating at the permissive temperature of $25^{\circ} \mathrm{C}$ and picking colonies after three days. Spontaneous cymA2 $\operatorname{trz}^{\mathrm{r}}$ double mutants arose at a frequency of $10^{-6}$. The genotype of these strains was confirmed by transducing both the cymA2 and the trz ${ }^{\mathrm{r}}$ markers from the double mutant into cysD505 and cysAzI. The frequency of cotransduction of cymA2 and cys $D^{+}(84 \%)$ and of the trz lesion and cys $A^{+}(72 \%)$ were virtually identical to that obtained using the singly marked strains cymA2 and trzi Io as donors. The phenotype of the double mutants was determined by testing growth on MA, MA + cysteine, and MA + methionine at $37^{\circ} \mathrm{C}$. Of 17 examined, all grew well on MA + cysteine or methionine, and six grew on unsupplemented MA, suggesting that in these few at least the $\operatorname{trz}^{\mathrm{r}}$ mutation was suppressing the cym mutation. However, the growth of the apparently suppressed strains on MA was not normal. High density inoculum streaks on to MA $\left(37^{\circ} \mathrm{C}\right)$ produced relatively few isolated colonies of normal size ( 3 to $5 \mathrm{~mm}$ ); when these were similarly subcultured to MA, MA + cysteine, and MA+ methionine, this pattern was again observed on MA but growth was normal on the supplemented media. It would seem that the suppression is unstable, and there is now further evidence to support this (Kingsman, unpublished).

\section{DISCUSSION}

The phenotypic distinction between cym mutants and cys or met mutants seems very clear. Growth responses to methionine and cysteine (Table 2 and Figs. 3 and 4 ) and their precursors (Fig. $3 a$ ) support this and also relate cym mutants to the established pathways of S-amino acid metabolism in S. typhimurium (Fig. I). The division of the cym mutants into subgroups (Table 6) is based on: (i) their ability or inability to utilize sulphite as an alternative to cysteine; (ii) their complementation patterns both with each other and with cys mutants; (iii) the mapping data available (Tables 3,4 ), which is virtually complete in cotransduction terms but which could be improved if further cys deletions were available; (iv) the 
enzyme assays that have been carried out (Table 5), although there is a requirement for PAPS reductase assays (Fig. I) particularly to define precisely the nature of cymB mutants. There is a consistency in these data which indicates firmly that each cym mutant is deficient in a cysteine enzyme and that methionine relieves that deficiency. Since there is no evidence of conversion of methionine to cysteine in cym mutants, they may be leaky and methionine spares intracellular cysteine, or methionine may restore their cys enzyme activity, presumably via a component of the wild-type cysteine regulatory system.

Leakiness is unlikely on a number of counts. Although growth in MM varied between cym mutants (Fig. 3), the increase in turbidity of cultures of some strains such as cymAI or $\mathrm{B} 3$ during $7 \mathrm{~h}$ incubation indicated virtually no cell division. Also, the respective cys enzyme activities in cym $\mathrm{A}, \mathrm{Bb}, \mathrm{Bc}, \mathrm{D}$ and $\mathrm{C}$ mutants were either undetectable or very low, and certainly were very similar to those in equivalent non-leaky cys mutants (Table 5). This is also true for sulphite reductase levels in cymBb mutants assayed in toluenized bacteria. Finally, sparing by methionine is likely to be partially or completely dependent upon $m e t J$-mediated repression of methionine enzymes (Chater, 1970) and if it is a significant component of the response to methionine, cym metJ double mutants derepressed for methionine synthesis should require a greater minimum amount of methionine to give maximum growth. In fact there was no significant difference between cymA2 and cymA2 met $J$ mutants in their growth response to methionine.

Direct evidence for the restoration of cys enzyme activity is sparse. Clearly the S-assimilation pathway is required during the growth of cym mutants on methionine (Table 7). However, no methionine-mediated restoration of cys enzyme activity in cym mutants has been observed either in vitro (cell-free extracts) or in situ (toluenized bacteria). In vivo, S-assimilation is stimulated by methionine (Table 8). These anomalies may be due to instability of methionine-restored enzyme activity during the assay procedures. If enzyme activity in cym mutants is restored, it implies deficiencies in their cys gene expression at the transcriptional or translational level since it seems unlikely that methionine could restore cys enzyme activity at a post-translational level. Support for this comes from the location of most of the cym mutations at the ends of the cys genes (Fig. 5) and from the apparent polarity of cymAI and A7 (Table 5).

The unstable suppression by some trz $\mathrm{z}^{\mathrm{r}}$ mutations of the phenotype of the cymA2 mutant (and of other cym mutants - Kingsman, unpublished) is another interesting property. Recent findings suggest that plasmid formation is involved in some cases of mutation to $\operatorname{trz}^{\mathrm{r}}$ (Dr D. Hulanicka, personal communication) and that integration of this plasmid at or near the sites of the cym mutations is responsible for the suppression (Kingsman, unpublished). Similar integrative events have been found for the galOP region of $E$. coli (Saedler et al. 1974).

Research studentships from the Wellcome Trust (to M.A.Q.) and Medical Research Council (to A.J.K.) are gratefully acknowledged, as are research funds from the Science Research Council (to D.A.S.). Some of this work was included in theses submitted to the University of Birmingham (by M.A.Q.). Valuable discussions have been enjoyed with Drs D. Hulanicka (Polish Academy of Sciences), J. Cole (Biochemistry Department, Birmingham University) and P. Piggot (National Institute for Medical Research, Mill Hill, London). Without the excellent technical support of Mrs Jacqueline Dudley, Mrs Joyce Yeomans and Mr J. Edgerton, the work would not have been possible. 


\section{REFERENCES}

AHMED, A. (1973). Mechanism of methionine biosynthesis in Escherichia coli. I. The role of methionine, S-adenosylmethionine and methionyl-transfer ribonucleic acid in repression. Molecular and General Genetics 123, 299-324.

Bhuvaneswaran, C., Sreenivasan, A. \& Rege, D. V. (1964). Effect of cysteine on respiration and catalase synthesis by Saccharomyces cerevisiae. Biochemical Journal 92, 504-508.

ChATER, K. F. (1970). Dominance of the wild-type alleles of methionine regulatory genes in Salmonella typhimurium. Journal of General Microbiology 63, 95.

Clowes, R. C. (1958). Nutritional studies of cysteineless mutants of Salmonella typhimurium. Journal of General Microbiology r8, 140-153.

DatTA, P. (1967). Regulation of homoserine biosynthesis by L-cysteine a terminal metabolite of a linked pathway. Proceedings of the National Academy of Sciences of the United States of America 58, 635-64I.

Delavier-Klutchko, C. \& Flavin, M. (1965). Enzymatic cleavage and synthesis of cystathionine in fungi and bacteria. Journal of Biological Chemistry 240, 2537-2549.

Demerec, M., Gillespie, D. H. \& Mizobuchi, K. (I963). Genetic structure of the cysC region of the Salmonella genome. Genetics 48, 997-1009.

Dreyfuss, J. (1964). Characterization of a sulphate- and thiosulphate-transporting system in Salmonella typhimurium. Journal of Biological Chemistry 239, 2292-2297.

Dreyfuss, J. \& Monty, K. J. (I963). The biochemical characterization of cysteine requiring mutants of Salmonella typhimurium. Journal of Biological Chemistry 238 , 1019-1024.

Eisenstark, A., Eisenstark, R. \& van Sickle, A. (I965). Mutation of Salmonella typhimurium by nitrosoguanidine. Mutation Research 2, I-IO.

Ellis, R. J. (1964). A rapid assay for sulphite reductase. Biochimica et biophysica acta 85, 335-338.

FeIGl, F. (1947). Qualitative Analysis by Spot Tests. New York: Elsevier.

Flavin, M., Delavier-Klutchko, C. \& Slaughter, C. (1964). Succinic ester and amide of homoserine: some spontaneous and enzymatic reactions. Science, New York 143, 50-52.

Hartman, P. E., Hartman, Z. \& Šerman, B. (1960). Complementation mapping by abortive transduction of histidine requiring Salmonella mutants. Journal of General Microbiology 22, 354-368.

Hilz, H., Kittler, M. \& KNaPe, G. (1959). Die Reduktion von Sulfat in der Leife. Biochemische Zeitschrift 332, I $5 \mathrm{I}-\mathrm{I} 66$.

Hobson, A. C. (1974). The regulation of methionine and S-adenosylmethionine biosynthesis and utilization in mutants of Salmonella typhimurium with defects in S-adenosylmethionine synthetase. Molecular and General Genetics 131, 263-273.

Hockenhull, D. J. D. (1949). The sulphur metabolism of mould fungi. The use of biochemical mutant strains of Aspergillus nidulans in elucidating the biosynthesis of cysteine. Biochimica et biophysica acta $\mathbf{3}$, 325-335.

HulanickA, D. (1972). Resistance to sulphate analogues in Salmonella typhimurium. Acta biochimica polonica 19, 367-375.

Hulanicka, D. \& KLOPOtowski, T. (1972). Mutants of Salmonella typhimurium resistant to triazole. Acta biochimica polonica 19, 25 I-260.

Hulanicka, D., Klopotowski, T. \& Smith, D. A. (1972). The effect of triazole on cysteine biosynthesis in Salmonella typhimurium. Journal of General Microbiology 72, 29I-30I.

Jones-Mortimer, M. C. (1968). Positive control of sulphate reduction in Escherichia coli. The nature of the pleiotropic cysteineless mutants of E. coli KI 2. Biochemical Journal 110, 597-602.

KREDICH, N. M. (197I). Regulation of L-cysteine biosynthesis in Salmonella typhimurium. I. Effects of growth on varying sulphur sources and $O$-acetyl-L-serine on gene expression. Journal of Biological Chemistry 246, 3474-3484.

LAmpen, J. O., Roepke, R. R. \& Jones, M. J. (1947). Studies on the sulphur metabolism of E. coli. III. Mutant strains of $E$. coli unable to use sulphate for their complete sulphur requirements. Archives of Biochemistry $\mathbf{1 3}, 55-66$.

Lowry, O. H., Rosebrough, N. J., FarR, A. L. \& Randall, R. J. (I95I). In Methods in Enzymology, vol. 3. Edited by S. P. Colowick and N. O. Kaplan. New York: Academic Press.

Margolis, D. \& MANDL, R. H. (1958). A system for separating sulphur and non-sulphur amino compounds by two-dimensional paper chromatography. Contributions to the Boyce-Thompson Institute I9, 509-5I 2.

Mizobuchi, K., Demerec, M. \& Gillespie, D. H. (1962). Cysteine mutants of Salmonella typhimurium. Genetics 47, I6I7-1627. 
Moore, S. \& Stein, W. H. (1963). Chromatographic determination of amino-acids by the use of automatic recording equipment. In Methods in Enzymology, vol. 6. Edited by S. P. Colowick and N. O. Kaplan. New York: Academic Press.

NAGY, Z., KarI, C. \& HeRNÁDI, S. (1969). Growth of Escherichia coli cells in the presence of cysteine on sulphate-deficient media. Archiv für Mikrobiologie 65, 39I-398.

Pardee, A. B. \& Prestidge, L. S. (I966). Cell-free activity of a sulphate binding site involved in active transport. Proceedings of the National Academy of Sciences of the United States of America 55, I89-19.

PASTERnAK, C. A. (1962). Sulphate activation and its control in Escherichia coli and Bacillus subtilis. Biochemical Journal 85, 44-49.

Postgate, J. R. (1963). The examination of sulphur auxotrophs: a warning. Journal of General Microbiology 30, $48 \mathrm{I}-484$.

Qureshi, M. A. (1968). Cysteine-methionine mutants of Salmonella typhimurium: physiological and genetical studies. M.Sc. thesis, University of Birmingham.

QURESHI, M. A. (197I). Genetical and biochemical aspects of the relationship between cysteine and methionine biosynthesis in Salmonella typhimurium. Ph.D. thesis, University of Birmingham.

Roberts, R. B., Abelson, P. H., Cowie, D. B., Bolton, E. T. \& Britten, R. J. (I955). Studies of Biosynthesis in E. coli. Publication no. 607 of the Carnegie Institution of Washington.

SAedler, H., Reif, H. J., Hu, S. \& Davidson, D. (I974). IS2, a genetic element for turn-off and turn-on of gene activity in E. coli. Molecular and General Genetics 132, 265-289.

SANDERSON, K. E. (1972). Linkage map of Salmonella typhimurium. Edition IV. Bacteriological Reviews 36, 558-586.

Sмiтн, D. A. (1961). Some aspects of the genetics of methionine-less mutants of Salmonella typhimurium. Journal of General Microbiology 24, 335-353.

Sмiтh, D. A. (1971). S-amino acid metabolism and its regulation in Escherichia coli and Salmonella typhimurium. Advances in Genetics 16, 14I-165.

Sмith, D. A. \& Childs, J. D. (I966). Methionine genes and enzymes of Salmonella typhimurium. Heredity 21, 265-286.

Smith, H. O. \& Levine, M. (I967). A phage P22 gene controlling integration of prophage. Virology 3r, $207-216$.

SмIтн, I. (1958). Chromatographic Techniques-Clinical and Biochemical Applications. London: Heinemann, Medical Books Ltd.

Tonomura, K. \& Novelli, G. D. (I960). Cysteine inhibition of the release of repression of dihydroorotic acid dehydrogenase in E. coli. Biochemical and Biophysical Research Communications 2, 3I-34.

Whitehouse, J. M. \& SMIth, D. A. (I973). Methionine and vitamin BI 2 repression and precursor induction in the regulation of homocysteine methylation in Salmonella typhimurium. Molecular and General Genetics 120, 34I-353.

Whitehouse, J. M. \& SMith, D. A. (I974). The involvement of methionine regulatory mutants in the suppression of BI2-dependent homocysteine transmethylase (met $H$ ) mutants of Salmonella typhimurium. Molecular and General Genetics 129, 259-267.

Wilson, L. G. \& BANDURSKI, R. S. (I958). Enzymatic reactions involving sulphate, sulphite, selenate and molybdate. Journal of Biological Chemistry 233, 975-98I . 